\title{
Analysis of Water Availability in Tuban Regency Watershed Area
}

\author{
Marita Ika Joesidawati ${ }^{1} \quad$ Suwarsih $^{1} \quad$ Lilik Kartika Sari $^{2}$ \\ 1.Faculty of Fisheries and Marine Science, Universitas PGRI Ronggolawe, Tuban \\ 2.Faculty of Fisheries and Marine Science, Universitas Jendral Soedirman , Purwokerto
}

\begin{abstract}
The impacts of climate change can affect the water availability of watershed in Tuban Regency, especially those that flow into the sea as much as 17 watersheds. The purpose of this study is to analyze the variables of temperature and rainfall associated with climate change on water availability in 2050. Projection methods for the climate change using Magicc/SCengen, image processing to obtain vegetation index and land cover type. Groundwater calculation using direct runoff and base flow analysis. The results show the projections in 2050 are trend raising in temperature and trend descend in rainfall, and the water availability is still sufficient assuming a decrease in forest area due to development.
\end{abstract}

Keywords: Soil Conservation Service, Penman, Climate Scenario, Climate Model, NDVI

DOI: $10.7176 / \mathrm{JEES} / 9-1-06$

\section{Introduction}

Climate change is the most interesting problem, because it is a very long process and its impact is difficult to predict appropriately and greatly affects the natural and social environment. Indonesia, as a country with a very large population with low economic capability, shows that Indonesia is in a condition that is prone to climate change. The impact of global climate change can be perceived in Indonesia such as unpredictable weather and increasing the extreme weather. The climate change condition in Indonesia is a topic that is too broad and needs assessment in various fields so that a comprehensive review of the impacts of climate change requires special scientific studies (Joesidawati, 2016).

The main problem of human needs affected as a result of climate change is the availability of water. According to Vörösmarty (2000), increasing population in the world also increases the need for water, while the water availability affected by an increase in evaporation due to the earth surface temperature enhancement. This condition shows the correlation between the need for integrated water resource management. And if it is not carried out there will be an impact on the damage to water resources in physically and institutionally which then also affects the socio-economic of the society.

Water management in Indonesia is currently in the deficient category (Kaimaduddin, et al, 2000). The approach that was taken should produce a comprehensive and environmentally sustainable solution so that a study is needed that can formulate a balanced and harmonious decision between the social, environmental, and economic functions of water resources. Referring to the problems that exist in Tuban Regency regarding with water scarcity in the availability of water during the dry season, a study is needed to analyze the impacts of climate change on the water availability in the Watershed of Tuban Regency, especially those that flow into the sea. The research aims to (1) analyze problems related to variables that associated with climate change, namely temperature and rainfall, (2) assess water availability with these variables to the availability of water until 2050. It is expected that the results of this study can be used as the basis for managing water use over the availability of water in 17 watersheds could manage the fulfillment of water needs both domestically and non-domestically (industry, agriculture, and fisheries) especially in facing the water crisis in the dry season.

\section{Method}

\subsection{Study Area}

This research was conducted in the watershed of Tuban Regency, East Java Province, which took place in July 2017 to May 2018. Research locations in 17 watersheds which are part of the Prumpung Klero Watershed Area Unit (WAU) (Figure 1). The rivers contained in the Prumpung Klero WAU mostly come from the North Coast. Tuban Regency is divided into 2 WAU namely Bengawan Solo WAU and Prumpung Klero WAU. 


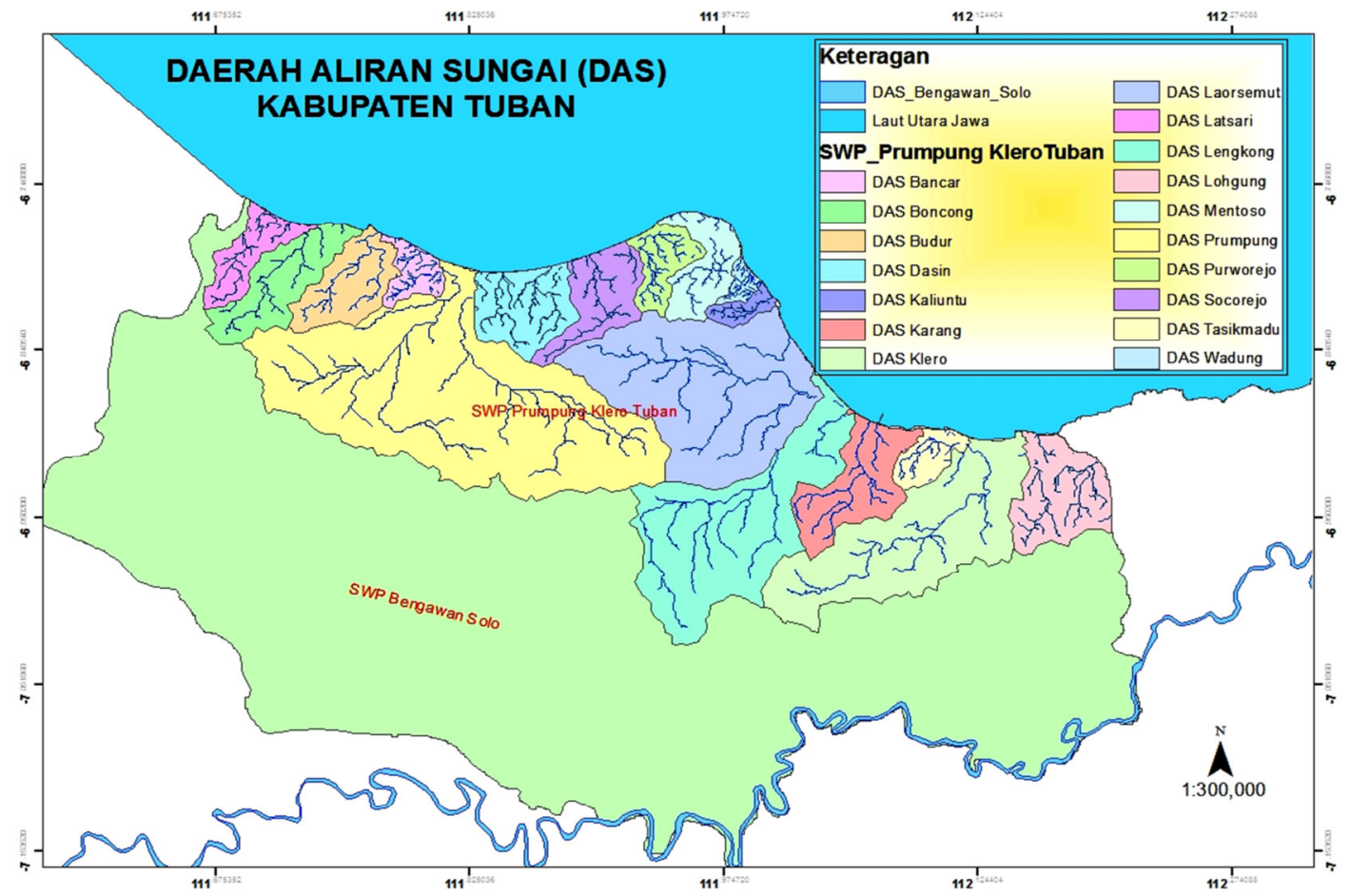

Figure 1. Research Location, 17 watersheds in Tuban Regency are Prumpung Klero WAU

Tuban Regency is also crossed by the Bengawan Solo River (as shown in Picture 1). Bengawan Solo WAU has several watersheds, one of the biggest is in Tuban Regency is the Kening River watershed that passes in the southern part of Tuban Regency which stretches from Jatirogo, Kenduruan, Bangilan, Singgahan, Senori and Parengan Districts.

\subsection{Climate Data and Groundwater Calculations}

Variables used to obtain groundwater variables are climate data in the form of temperature $\left({ }^{\circ} \mathrm{C}\right)$, rainfall $(\mathrm{mm})$, surface wind speed $(\mathrm{m} / \mathrm{s})$, irradiation time (hours) and solar radiation $(\mathrm{cal} / \mathrm{m})$. The data is processed based on Penman equations to obtain evapotranspiration values. The Penman equation consists of 3 equations, those are: The first equation:

which:

$$
E=\frac{\mathrm{HA}+0.27 \mathrm{Ea}}{\mathrm{A}+0.27}
$$

$\mathrm{E}=$ evapotranspiration

$\mathrm{A}=$ the slope of the saturated vapor pressure at air temperature

$\mathrm{Ea}=$ evaporation

$\mathrm{H}=$ transpiration equation

The second equation:

$$
\mathrm{H}=\mathrm{R}(1-\mathrm{r})(0.18+0.5 \mathrm{~S})-\mathrm{B}\left(0.65-0.092 \sqrt{e_{d}}\right)(0.1+0.9 \mathrm{~S})
$$

$$
\text { which: }
$$

$\mathrm{R} \quad=$ solar radiation on a horizontal surface

$\mathrm{r} \quad=$ reflection coefficient

$\mathrm{S} \quad=$ solar radiation (sunshine)

$\mathrm{e}_{\mathrm{d}} \quad=$ actual vapor pressure

The third equation:

$$
\mathrm{E}_{\mathrm{a}}=0.35\left(\mathrm{e}_{\mathrm{a}}-\mathrm{e}_{\mathrm{d}}\right)\left(\mathrm{k}+0,01 \mathrm{~W}_{2}\right)
$$

which:

$\mathrm{e}_{\mathrm{a}} \quad=$ pressure saturated steam at an average temperature

$\mathrm{k}=$ roughness coefficient

$\mathrm{W}_{2}=$ wind speed at 2 meters height

After obtaining evapotranspiration values, a direct runoff calculated from the rainfall using the Soil Conservation Service (SCS) Method. SCS Equation (USDA, 1986): 


$$
\mathrm{Q}=\frac{(P-0.2 S)^{2}}{(P+0.8 S)}
$$

which:

$\mathrm{Q}=$ Direct Runoff (inch)

$\mathrm{P}=$ Rainfall (inch)

$\mathrm{S}=$ Maximum retention (inch)

The $\mathrm{S}$ value is related to the soil condition and land cover shown through the Curve Number $(\mathrm{CN})$ between 0 100

$$
\mathrm{S}=\frac{1000}{C N}-10
$$

In determining the amount of $\mathrm{CN}$, factors that need to be considered are: soil type, soil moisture, land cover, and hydrological conditions. Base flow is calculated through the Penman Method equation. Whereas runoff is the amount of base flow with direct runoff. With the SCS method, the direct runoff value is obtained, then the base flow value is also known.

The output generated from the equation above is a change in the current condition of the river body which incorporates elements of the climate change. So this formulation is a river adaptation strategy for climate change. Then the policies that would be made not only include river biophysics factors but include the other factors such as climate and weather variations.

\subsection{Climate Change Predictions}

The data used in this study are climatological data, which are (1) monthly rainfall data in Tuban Regency obtained from 27 rainforest stations in 2000 - 2017 from Regional Development and Infrastructure Service, Irrigation Division in Tuban Regency, (2) solar radiation data obtained from Perak Meteorological Station II (Maritime) Surabaya in 2000 - 2017, (3) air temperature data was obtained from Meteorology Climatology and Geophysics Council of Surabaya and Environmental Agency of Tuban from 2000 - 2017, (4) Digital Elevation Data of NASA Shuttle Radar Topography Mission (SRTM) $90 \mathrm{~m}$ version 4, which was downloaded at http://srtm.csi.cgiar.org/. To obtain digital watershed data in Tuban Regency, it was processed using the ArcGIS 10.2.2 application, (5) the location of the observation station/rain gauge, at each observation location will have different rainfall and air temperature values interpolated by forming grid geostatistic using the Kriging method. This Kriging method according to (Muller, 2013) can predict a value of a point in each grid approaching its true value.

The prediction of the climate change impact on the water availability in Tuban Regency Watershed was developed with a non-linear equation in each point of climatological data. These non-linear equations are extrapolated to obtain spatial projections and temporal for rainfall and temperature of the watershed in Tuban Regency. The results obtained were validated by climate change predictions on the water availability in Tuban Regency watershed generated by the software named MAGICC/SCENGEN 5.3 (Model for the Assessment of Greenhouse-gas Induced Climate Change/SCENario GENerator) by using climate scenarios and models that are appropriate to the local region.

\section{Image Processing}

Image processing used to obtain vegetation index and type of land cover. NDVI is obtained from Landsat 8 imagery (08-08 2018) and Landsat 7 ETM + imagery (09-09-2000). Vegetation index (NDVI/Normalized Difference Vegetation Index) to determine the vegetation conditions at the study site. According to Ren se al., (2011) by knowing NDVI, it is also known that the amount of solar radiation absorption (PAR/Photosynthetically Active Radiation) in the leaves of plants. The equation for calculating NDVI:

which:

$$
\mathrm{NDVI}=\frac{N I R-R E D}{N I R+R E D}
$$

NIR $=$ spectrum near - infrared

$\mathrm{RED}=$ spectrum infra red

Nilai NDVI beetwen -1.00 to +1.00

The type of land cover was obtained from processing Landsat $8+$ OLI imagery which was overlaid with the RBI map in 2014. The entire image processing process uses ENVI 5.4 and ArcGIS 10.2.2 
The work steps of this research are as in Fig 2:

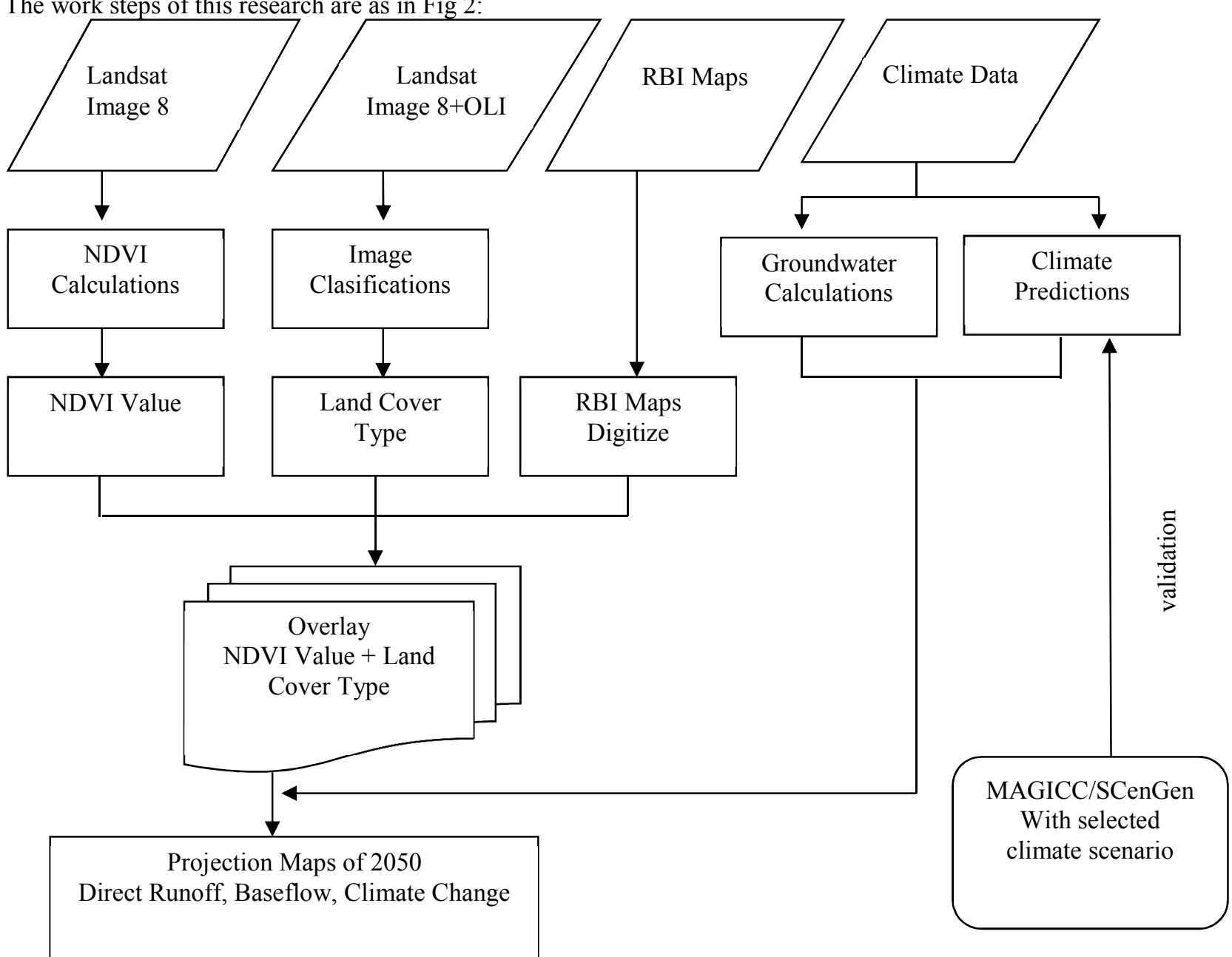

Figure 2. Flowchart of Methodology Research

\section{Results And Discussion}

\subsection{Climate Change Predictions}

The results of the prediction of climate change on the water availability in Tuban Regency watershed using the MAGICC/SCENGEN 5.3 Software are used as validation. But the MAGICC/SCENGEN variable should be adjusted to the conditions of the study area in order to obtain the right results and in accordance with the conditions in the study area. The selection of climate scenarios (wisdom scenarios and reference scenarios) as variables or as models is carried out by analyzing statistical data from economic growth, environmental management, calculation of CO2 emissions, temperature increases and so on (IPCC, 2007). Dessai et al. (2005) has been discussed the role of climate scenarios needed for adaptation to climate change. In the case of this multinational watershed adaptation program, the impact assessment is very quantitative through the modeling work done to estimate the possible implications of climate and changes in land cover for water sources and affected sectors (agriculture, freshwater fisheries, aquatic environment), and for people's lives.

Joesidawati, (2012) conducted a study of climate scenarios and models were in accordance with Tuban Regency as B2-AIM and A2 AIM policy scenarios and WRE 550 reference scenarios that use the stability of $\mathrm{CO}_{2}$ concentrations of $550 \mathrm{ppm}$, for reasons as shown in Table 1. 
Table 1. Reasons for Determining Climate Scenarios (Emission Scenarios and Policy Scenarios) for Tuban Regency

\begin{tabular}{|c|c|}
\hline Selected Climate Scenario & Selected Reason \\
\hline \multicolumn{2}{|l|}{$\mathrm{A} 2 *$} \\
\hline $\begin{array}{l}\text { Regional-oriented economic } \\
\text { development } \\
\text { The temperature increase in } 2100 \text { is } \\
\text { between } 2.0-5.4{ }^{\circ} \mathrm{C}\end{array}$ & $\begin{array}{l}\text { 1. Based on the GRDP data at current prices according to the 2010- } \\
2015 \text { business field and the } 2011-2015 \text { gross regional domestic } \\
\text { product aggregate shows the main economic drivers in sequential } \\
\text { Tuban are from the manufacturing industry; the agriculture, } \\
\text { forestry and fisheries sectors: construction sector: and the trade } \\
\text { sector, and these four sectors also contribute emission contributors. } \\
\text { 2. Income per capita is still low with an average of } 5 \text { years per year is } \\
\text { Rp. } 23,514,093 \text {, - so that the goal of economic development still } \\
\text { increase the regional domestic products, there are high interval in } \\
\text { the main productivity and productivity resources of the economy } \\
\text { from the sectors of agriculture, forestry and fisheries. But still rich } \\
\text { in natural resources }\end{array}$ \\
\hline \multicolumn{2}{|l|}{$\mathrm{B} 2 *$} \\
\hline $\begin{array}{l}\text { Managing the local environment } \\
\text { The temperature increase in } 2100 \text { is } \\
\text { between } 1.4-3.8^{\circ} \mathrm{C}\end{array}$ & $\begin{array}{l}\text { 1. Environmental management in Tuban still handled by local } \\
\text { institutions related to its fields, for example, environmental service, } \\
\text { fisheries and marine services, irrigation sub-offices and so on. } \\
\text { 2. Decision making in environmental management is the relevant and } \\
\text { informed agency in the surrounding community through } \\
\text { stakeholder who are aware of the importance of a sustainable } \\
\text { environment. } \\
\text { 3. Large industrial activities in Tuban Regency are equipped with } \\
\text { AMDAL, so that environmental management can be sustainable. } \\
\text { 4. The increasing temperature in Tuban Regency in } 2100 \text { was } 1.69 \\
{ }^{\circ} \mathrm{C} \text {, with reference to } 2000\end{array}$ \\
\hline \multicolumn{2}{|l|}{$\mathrm{AIM}^{* *}$} \\
\hline $\begin{array}{l}\text { The commonly model that used to } \\
\text { analyze the effects of climate change } \\
\text { in the Asia Pacific region, developed } \\
\text { by NIES and Kyoto University, Japan }\end{array}$ & $\begin{array}{l}\text { 1. Tuban Regency is included in the ASIA region (Southeast Asia- } \\
\text { Indonesia) and based on research by Morita et al, (1994); Kainuna } \\
\text { et al (1999 a, } 1999 \mathrm{~b} \text { ) can be used for local areas on a small scale. } \\
\text { 2. AIM's climate model can evaluate the policy options for reducing } \\
\mathrm{CO}_{2} \text { emissions in the Asia-Pacific region }\end{array}$ \\
\hline \multicolumn{2}{|l|}{ WRE $550 * * *$} \\
\hline $\begin{array}{l}\text { Stabilization scenario, which can } \\
\text { stabilize } 550 \text { ppm of } \mathrm{CO} 2 \\
\text { concentration if combined with } \mathrm{A} 2 \\
\text { and } \mathrm{B} 2 \text { emission scenarios } \\
\text { One of the policy scenarios expected } \\
\text { in } 2100 \text { can reduce emissions }\end{array}$ & $\begin{array}{l}\text { 1. The largest amount of emissions produced in Tuban based on } \\
\text { emissions per category of emitting producers activities from the } \\
\text { mineral industry sub-sector, that is } 16,311,287 \text { tons of } \mathrm{CO}_{2} \mathrm{e} \text { from } \\
\text { the total emissions produced by } 27,940,361 \text { tons of } \mathrm{CO}_{2} \mathrm{e} \text { (in 2014) } \\
\text { 2. The largest amount of emissions produced in Tuban based on total } \\
\text { emissions per gas type from all contributing sectors to emissions in } \\
2014 \text { came from carbon dioxide }\left(\mathrm{CO}_{2}\right) \text { of } 25,741,284 \text { tons of } \mathrm{CO}_{2} \mathrm{e} \\
\text { from the total emissions produced by } 27,940,361 \text { tons of } \mathrm{CO}_{2} \mathrm{e} \text { (in } \\
\text { 2014) } \\
\text { 3. Based on the emissions calculation for } 4 \text { years the average } \\
\text { emissions produced were } 19,819,496 \text { tons of } \mathrm{CO}_{2} \mathrm{e} \text { (per sector of } \\
\text { activity and per type of gas) so in Tuban it is necessary to control } \\
\text { emissions or reduce emissions }\end{array}$ \\
\hline
\end{tabular}

* Emission Scenario of The fourth Asessment Report of The Intergovermental Panel on Climate Change (AR4IPCC, 2007), which are A2 dan B2 (Regionalisation: is a heterogen sphere) and A2 more focus on economic sector while B2 more focuse on environmental sector

** AIM (the Asian-Pasific Integrated Model) is a model that used to developing the SRES (Special Report on Emission Scenarios) (IPCC, 2001).

*** Policy scenario used to stabilizing $\mathrm{CO}_{2}$ on atmosphere atmosfer in range $450,550,650$, and $750 \mathrm{ppmv}$ (IPCC, 2001)

Source: Joesidawati, 2016

The prediction results of temperature and rainfall in Tuban Regency $\left(111^{\circ} 30^{\prime}-112^{\circ} 35^{\prime}\right.$ EL and between $6^{\circ} 40$ '- $7^{\circ} 18^{\prime} \mathrm{SL}$ ) using MAGICC/SCENGEN based on selected climate scenarios (A2-AIM and B2-AIM) and 

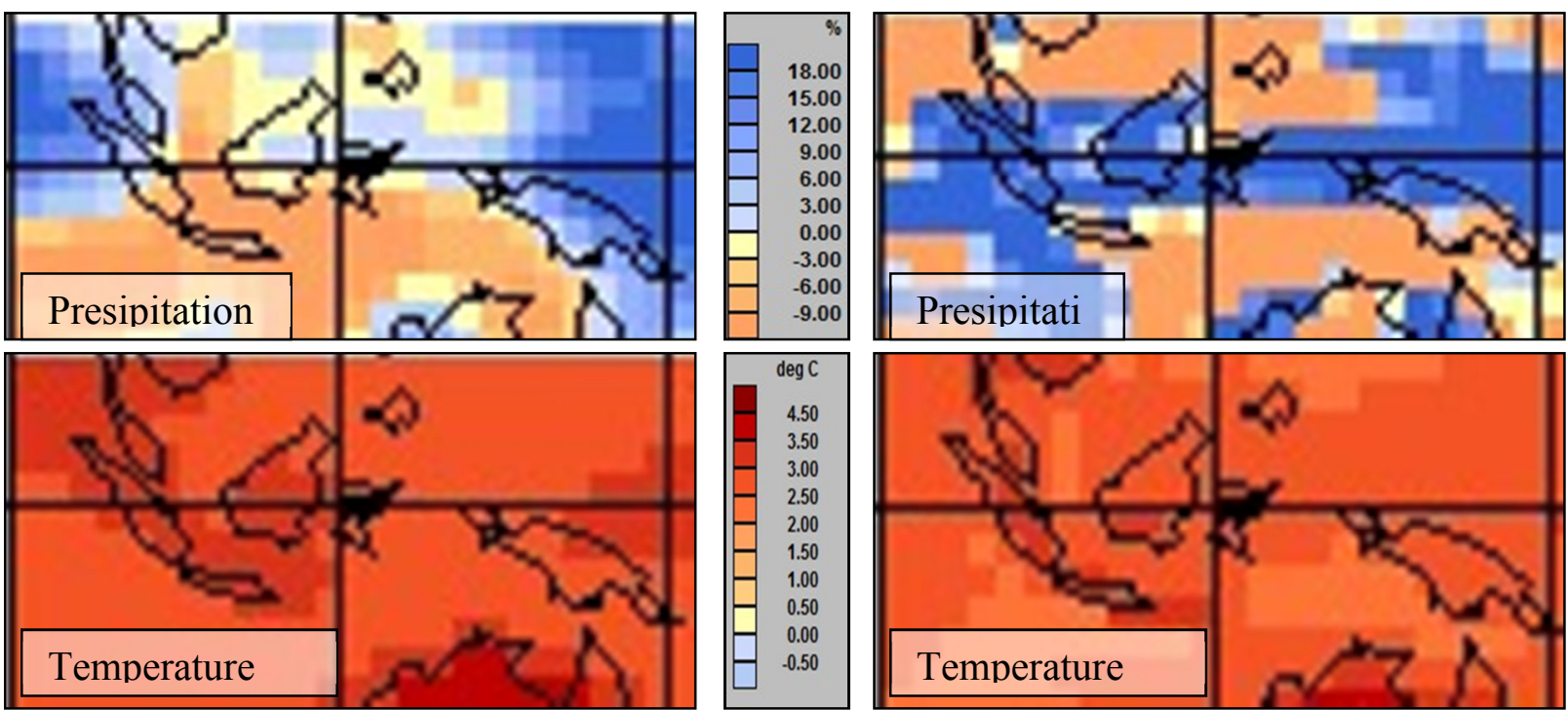

Figure 3. Climate Change Prediction in 2100 (Precipitation and Air Temperature) using A2-AIM and B2-AIM

Climate Scenarios, as well as the CCSM-30 and CSIRO-30 Models

In Figure 3, shows that in 2050 the air temperature increased by an average of $2.51{ }^{\circ} \mathrm{C}-3.52$, while the precipitation has decreased of $0.8-12.3 \%$, means that if the appropriate adaptation steps were not taken, then the chance of water drought occurring during the dry season will continue to increase.

\subsection{Land Use Transformation Analysis}

Lacking availability of clean water is one of the causes land transformation from vegetation land to nonvegetation (Puradimaja, 2006). The amount of DRO (direct runoff) will also increase with decreasing infiltration. Based on the results of the NDVI calculation shows the location of the study occurred a significant change, where the value of NDVI is positive, which means that the land in the watershed undergoes a change mainly turns into residential land and no longer as a vegetation area. Table 2. It is the result of processing the land cover area processed by ArcGis10.2.2 which is the result of delineation of Landsat 7 ETM + Image (2000) and Landsat Image 8 (2017).

Tabel 2. Land Use at 2001 and 2017 in 17 watershed study areas

\begin{tabular}{|l|l|r|r|}
\hline No & \multicolumn{1}{|c|}{ Land Cover } & Large $\left(\mathrm{m}^{2}\right)$ in 2000 & \multicolumn{1}{|c|}{ Large $\left(\mathrm{m}^{2}\right)$ in 2018} \\
\hline 1 & Forest & $218,791,653.79$ & $218,791,653.79$ \\
\hline 2 & Industry & $33,462,163.84$ & $77,665,305.37$ \\
\hline 3 & Settlement & $55,285,539.38$ & $138,945,379.45$ \\
\hline 4 & Field Rice & $291,872,133.77$ & $208,212,293.70$ \\
\hline 5 & Embankment & $7,601,303.11$ & $7,601,303.11$ \\
\hline 6 & Moor land & $244,017,234.80$ & $199,814,093.27$ \\
\hline
\end{tabular}

In Table 2 shows a vegetation area reduction to non-vegetation. Cutting mangrove areas into ponds or industries, vacant land into residential areas has been seen in almost everywhere in the study area. It can be interpreted as natural land use (forests, gardens, and vacant land) into residential or industrial areas. This includes the construction of transportation facilities and infrastructure (making roads, stations, and other facilities).

\subsection{Direct Runoff and Projection Analysis}

Direct Runoff (DRO) values depend on the type of soil, land cover, and rainfall, so that the value varied in different types of soil and land cover (Suryatmojo, 2015). As in the other regions of Indonesia, Tuban Regency consists of two seasons, which are the rainy and dry seasons (tropical climate) with an average temperature of $20^{\circ} \mathrm{C}-33^{\circ} \mathrm{C}$ with the type of climate that belongs to $\mathrm{C}$ and $\mathrm{D}$, where the wet months start from October to May, while the dry month is from July to September. The dry area is $94.73 \%$ with conditions ranging from mildly dry to very dry covering 19 sub-districts. While the remaining approximately $5.27 \%$ is a fairly wet area. Rainfall data from Tuban Regency comes from 28 rain water storages (Figure. 4) showing the average rainfall in March 2017 are 8.5 to $25.83 \mathrm{~mm}^{3}$. Rainfall in Tuban Regency in 2017 shows an average of $139 \mathrm{~mm}^{3}$ per month, with an 
average per day $16 \mathrm{~mm}$ and rainy days average is 103 from 28 rainfall storages (Table 3 ).

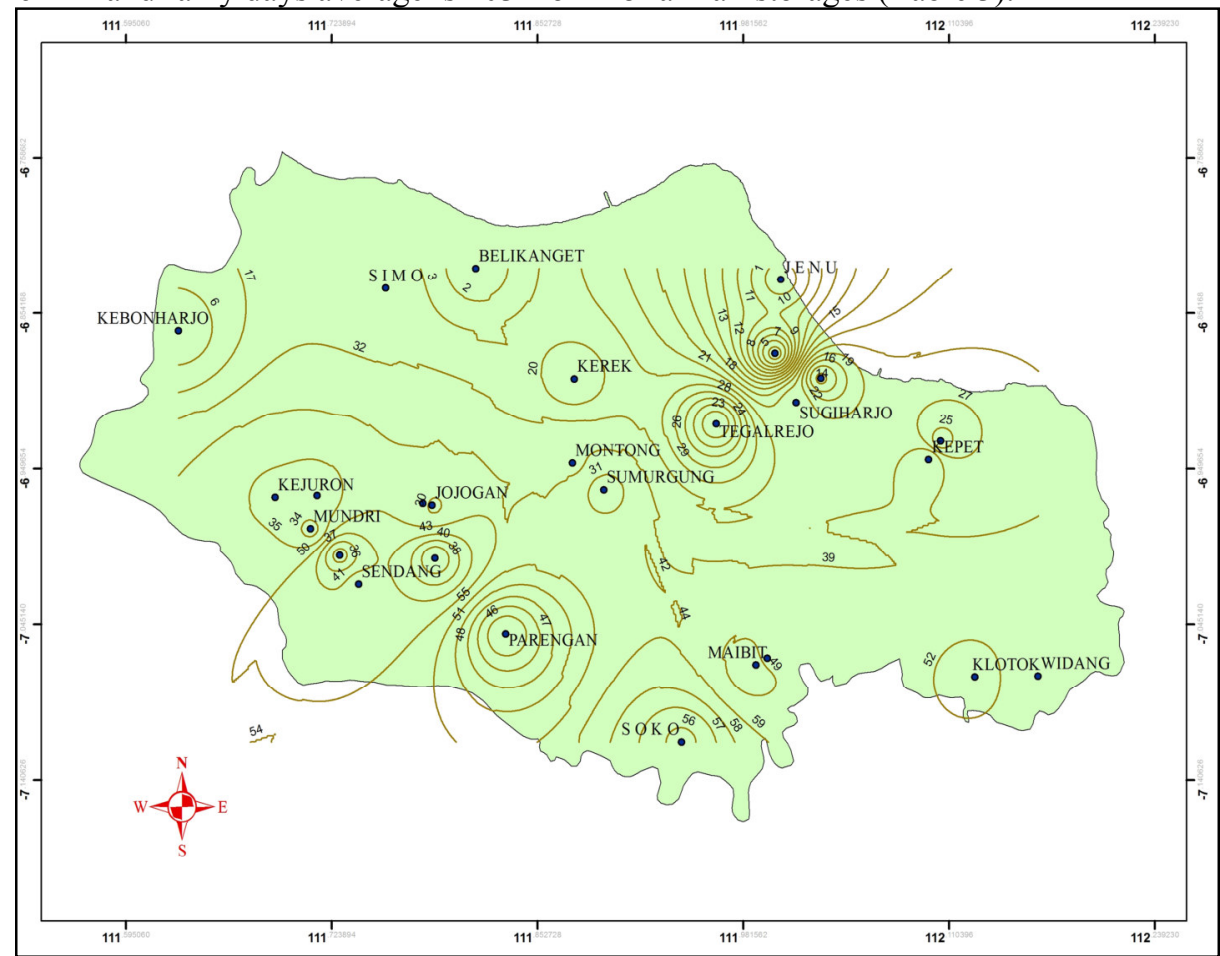

Figure 4. Isohyet Map of Rainfall Average in March 2017 in 28 Rainfall Locations in Tuban Regency

Tabel 3. Rainfall Average in Tuban Regency on 2017 in 28 rainfall storages location

\begin{tabular}{|c|c|c|c|c|c|c|c|}
\hline No & Station Name & \multicolumn{2}{|c|}{$\begin{array}{c}\text { Elevation from } \\
\text { Shvp }\end{array}$} & $\begin{array}{c}\text { Rainfall } \\
\left(\mathrm{mm}^{3}\right)\end{array}$ & $\begin{array}{l}\text { Rainy } \\
\text { day }\end{array}$ & $\begin{array}{c}\text { Per Day average } \\
\left(\mathrm{mm}^{3}\right)\end{array}$ & $\begin{array}{l}\text { Per month average } \\
\left(\mathrm{mm}^{3}\right)\end{array}$ \\
\hline 1 & BANGILAN & + & 62 & 1443 & 110 & 13.12 & 120.25 \\
\hline 2 & MUNDRI & + & 62 & 1533 & 111 & 13.81 & 127.75 \\
\hline 3 & KEJURON & + & 98 & 1600 & 132 & 12.12 & 133.33 \\
\hline 4 & $\mathrm{~L} \mathrm{~A} \mathrm{~J} \mathrm{U}$ & + & 47 & 2003 & 110 & 18.21 & 166.92 \\
\hline 5 & SENDANG & + & 45 & 1947 & 97 & 20.07 & 162.25 \\
\hline 6 & JOJOGAN & + & 90 & 2101 & 119 & 17.65 & 175.04 \\
\hline 7 & MONTONG & + & 168 & 2044 & 128 & 15.97 & 170.33 \\
\hline 8 & SUMURGUNG & + & 182 & 2213 & 132 & 16.77 & 184.42 \\
\hline 9 & BANYU URIP & + & 60 & 1785 & 122 & 14.63 & 148.75 \\
\hline 10 & NGABONGAN & + & 49 & 1933 & 99 & 19.53 & 161.08 \\
\hline 11 & KEBONHARJO & + & 90 & 1699 & 116 & 14.65 & 141.58 \\
\hline 12 & BELIKANGET & + & 16 & 1066 & 73 & 14.60 & 88.83 \\
\hline 13 & KEREK & + & 70 & 1705 & 65 & 26.23 & 142.08 \\
\hline 14 & $\mathrm{~S} \mathrm{I} \mathrm{M} \mathrm{O}$ & + & 40 & 1227 & 84 & 14.61 & 102.25 \\
\hline 15 & KEPET & + & 50 & 1174 & 96 & 12.23 & 97.83 \\
\hline 16 & TUBAN & + & 4 & 1297 & 74 & 17.53 & 108.08 \\
\hline 17 & BOGOREJO & + & 5 & 1130 & 84 & 13.45 & 94.17 \\
\hline 18 & TEGALREJO & + & 20 & 1524 & 87 & 17.52 & 127.00 \\
\hline 19 & SILOWO & + & & 1187 & 62 & 19.15 & 98.92 \\
\hline 20 & $\mathrm{~J}$ E N U & + & 4 & 1172 & 86 & 13.63 & 97.67 \\
\hline 21 & $\mathrm{~S} \mathrm{O} \mathrm{K} \mathrm{O}$ & + & 20 & 1975 & 145 & 13.62 & 164.58 \\
\hline 22 & RENGEL & + & 22 & 2142 & 133 & 16.11 & 178.50 \\
\hline 23 & MAIBIT & + & 22 & 1811 & 106 & 17.08 & 150.92 \\
\hline 24 & KLOTOK & + & 10 & 2288 & 115 & 19.90 & 190.67 \\
\hline 25 & WIDANG & & 5 & 2130 & 113 & 18.85 & 177.50 \\
\hline 26 & PALANG & & & 1315 & 87 & 15.11 & 109.58 \\
\hline 27 & NGIMBANG & & & 1347 & 90 & 14.97 & 112.25 \\
\hline 28 & PARENGAN & & & 2061 & 115 & 17.92 & 171.71 \\
\hline
\end{tabular}


The largest DRO value is in city land cover areas and clay type, this is due to the ability of the soil to absorb rainwater in urban areas is very small, considering that urban areas with more surface are covered by waterproof coating such as concrete and cement. The type of clay soil also affects the absorption capacity of rainwater into the soil, its large porosity causes water to be difficult or slow to get into the soil so that most of the rainwater that flows down the surface as a DRO. Clay soil has an absorption capacity of $0-1 \mathrm{~mm}^{3} /$ hour (Mirus et al., 2017). So if there is rain with an amount of $139 \mathrm{~mm}$, the water will continue to be on the surface for 200 hours (equivalent to 9 days). Based on Picture 5 with linear equation $y=41.117 x+953.38$ (total rainfall) and $y=2.6399 x+51.389$ (number of rainy days) then in 2050 shows an average of $252.51 \mathrm{~mm}^{3}$ per month, with an average per day of $15.92 \mathrm{~mm}^{3}$ with an average number of rainy days in a year of 190 days.(Figure 5)

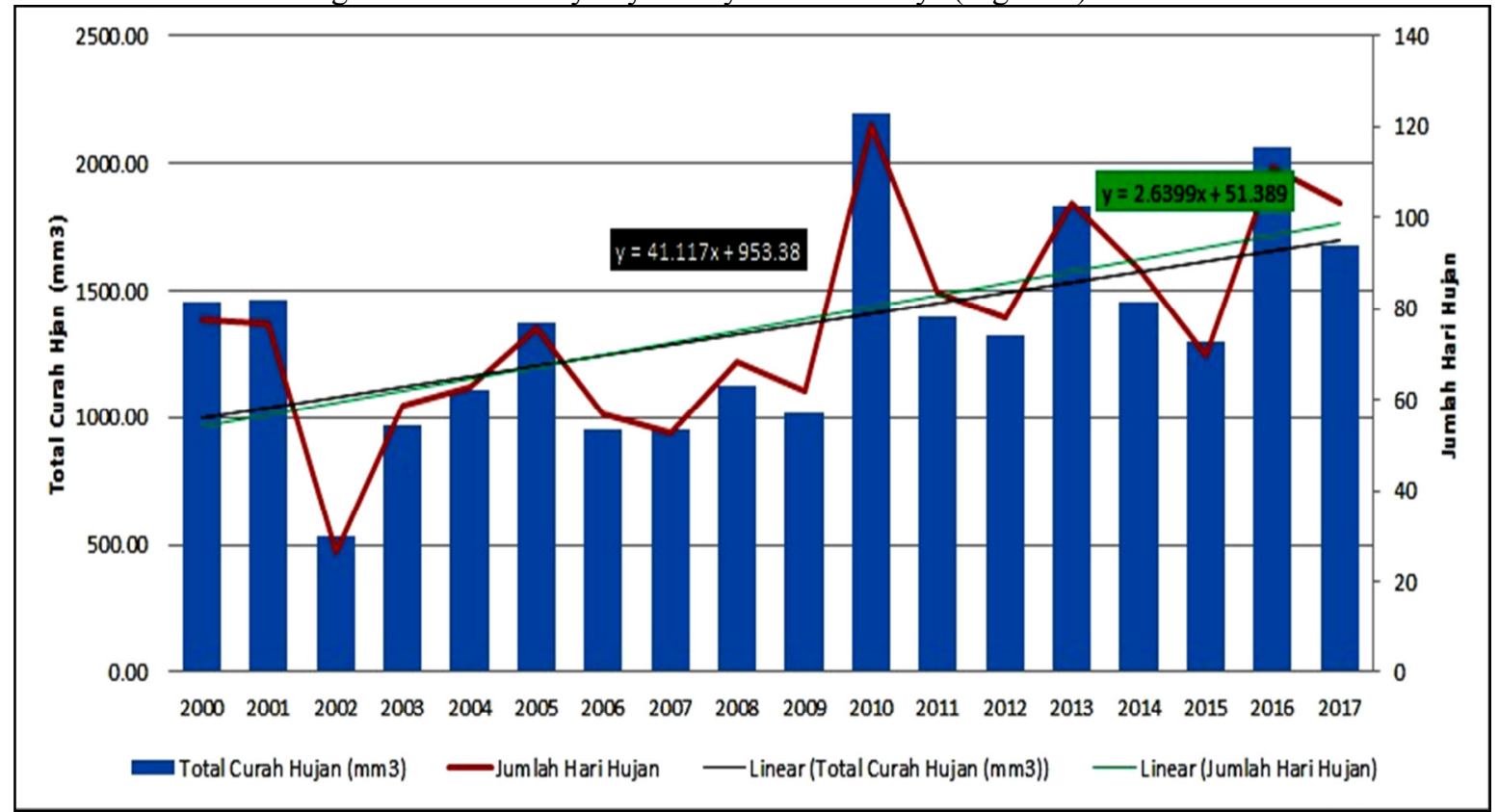

Figure 5 . The total of rainfall in Tuban Regency (2000-2017)

Then the DRO value in 2050 will be higher in accordance with the increase of rainfall that occurs is equal to $139.44 \mathrm{~mm}^{3}$ DRO value also rose to reach $65.25 \mathrm{~mm} 3$ and with the change in land cover (expanding urban areas), the areas with high DRO become more than 2017. This conditions will increase the chances of disasters in the study area, such as floods, landslides, river overflows, and crop failure. Therefore, an appropriate adaptation step is needed, so that the effects of climate change would not be worst expected. In addition, policies are also needed from the stakeholders, in this case the local government and other organizations related to the damage from climate change.

\subsection{Baseflow and Projection Analysis}

Base flow roughly reflects how much water reaches the groundwater reservoir (recharge) and also reflects how much water supplies a river or Lake (discharge). But in this study, the discharge process that occurs is not discussed. Which can be analyzed from the Penman equation to determine the amount of base flow is the amount of recharge that occurs in the groundwater reservoir at the study area. Base flow is directly affected by runoff and direct runoff. Therefore, base flow is also influenced by the amount of infiltration. Soil absorption of water plays an important role in infiltration, so the base flow value is also influenced by the type ofsoil and land cover.

In this study, the base flow value obtained comes from the DRO value that has already been obtained. For January 2017, the base flow value ranges from $0.15-104.55 \mathrm{~mm}$. If we associate with the amount of rainfall that occurs in the month of 2017, then the amount of water that has successfully recharged the study area is not up to $50 \%$ of the total amount of rainwater. It is seen that regions with a base flow more than 4 inches only occur in areas with type A soil, types of sand or soil that containing sand. While projected in 2050, it appears that there is a drastic change in base flow values. On 2050 base flow values range from 0.01 to 6.05 inches. Means changes occur the base flow maximum value is 2.02 inches in areas with type A.

Based on the results of the NDVI projection, this is due to land use transformations into solid, this could mean settlement development or become an industrial area or a highway. This condition would cause land water recharge reduced, consequently the availability of clean water will be limited, reciprocally with river discharge process. If the discharge process is inhibited/reduced, then this is eventually cause drought in the river. This will cause a kind varies problems such as drought, crop failure, and related social problems availability of water. In July 2017 the base flow of the research area $\mathrm{n}$ increase to $0.01-2.84$ inches of total rainfall of $22.96 \mathrm{~mm}^{3}$. 
Although the amount of rainfall that occurs is higher, but the amount of water that is isolated until the groundwater reservoir remains not up to $50 \%$ of the total rainfall that falls. But the interesting thing here is the amount of rainfall that occurred in July reached a value higher than the amount of rainfall in January. This is due to the average rainfall area. There are several observation stations that show rainfall anomalies in July, where in that month the amount of rainfall that occurred was higer than the amount of rainfall in January. However, if averaged between all existing observation stations, then the rainfall pattern that occurs still has a monsoon rainfall pattern. While the cause of the anomaly not to be known, because a further research is needed on the condition of the anomaly.

Base flow projection results in the year shows results that are not much different, ranging from 0.01 to 2.15 inches. This is still related to the persistently large amount of rainfall in July 2050, which is 16.75 inches. And this shows that infiltration is still low, because the biggest value of baseflow only occurs in a few areas in the study area (not reaching 20\% of the research area). Coupled with the conditions of land use transformations in the absorbsion area, it will cause the smaller baseflow to occur. And this condition is clearly very detrimental. From the those conditions, seems that the amount of baseflow is strongly related to land cover and the type of land in an area. For the current study area, soil type $\mathrm{C}$ (medium to high runoff potential) is very dominant, therefore the amount of water that can be isolated to the groundwater reservoir is relatively small compared to DRO. While the type of soil A (very low runoff potential) is very small, so even though in the study area the baseflow value is more than 1.2 inches, but the catchment area is very small (not reaching $20 \%$ of the total area of the study area).

\section{Conclusion}

Based on the results of the temperature variable projection, it is seen that the temperature shows an upward trend up to 2050, and will continue to do so for the future. The trend of gradual temperature rise is the indication of climate change in the study area. Temperature increases change rainfall conditions in terms of seasonal distribution for the study area. In general, the condition of the study area became wetter in the wet season and was drier during the dry season. Flood potential stronger in the northern region of the study area because the elevation of the northern region is gentler than the southern region. So that high rainfall will cause water to flow from south to north and potentially cause flash floods. In addition, these would be able to trigger river overflows, so it can cause flooding or puddles around the watershed. And the projection until 2050 is still sufficient (assuming that there is a decrease in the amount of forest area due to development), but it could be unfulfilled if in reality the development exceeds estimates, so the water catchment area will be decrease.

\section{Acknowledgement}

Thank you to the Tuban Public Works Agency, Irrigation Sector Division for all data in support of this research.

\section{Reference}

Dessai, S., Lu, X., and Risbey, J. S., (2005). On the role of climate scenarios for adaptation planning. Global Environmental Change 15: pp. 87-97.

Gerrit Muller, G. (2013) Systems Engineering Research Methods, Procedia Computer Science, Volume 16: $1092-1101$.

IPCC, 2001. Climate change 2001: Impacts, Adaptation And Vulnerability. Contribution Of Working Group II to The Third Assessment Report Of The Intergovernmental Panel on Climate Change. Cambridge University Press, Cambridge, UK and New York, USA.

IPCC, 2007. Climate change 2007: Impacts, Adaptation And Vulnerability. Contribution Of Working Group II to The Fourth Assessment Report Of The Intergovernmental Panel on Climate Change. Cambridge University Press, Cambridge, UK, 976 pp.

Joesidawati, M.I, (2012). Pemodelan Perubahan Iklim Daerah Kabupaten Tuban Menggunakan MAGGIC/SCENGEN. Agriekonomika. Volume I, Nomor I:77-83,

Joesidawati,M.I., (2016). Studi Perubahan Iklim dan Kerusakan Sumberdaya Pesisir di Kabupaten Tuban. Disertasi. ITS. Surabaya

Kaimuddin, (2000) Kajian Dampak Perubahan Iklim dan Tata Guna Lahan Terhadap Keseimbangan Air Wilayah Sulawesi Selatan. Disertasi Program Studi AGK-FPS IPB, Bogor.

Mirus, B. B., Smith, J. B., \& Baum, R. L. (2017). Hydrologic Impacts of Landslide Disturbances: Implications for Remobilization and Hazard Persistence. Water Resources Research, 53(10), 8250-8265.

Puradimaja, D.J., (2006). Hydrodynamic relationships between groundwater and river ater: Cikapundung River Stream, West Java. IAEG2006, Volume 488

Ren, Sheng-ming., Liang, Y., Sun, B.,(2011). Research on Sensitivity for Soil Erosion valuation from DEM and Remote Sensing Data source of Different Map Scales and Image Resolutions. Procedia Environmental Sciences $10: 1753-1760$ 
Suryatmojo,H. (2015).Rainfall-runoff Investigation of Pine Forest Plantation in the Upstream Area of Gajah Mungkur Reservoir, Procedia Environmental Sciences, Volume 28: 307-314.

USDA, (1986). Urban Hydrology for Small Watersheds. United States Department of Agriculture, Natural Resources Conservation Service Conservation Engineering, Division Technical, Release 55, June 1986

Vörösmarty,C.J., (2000) Global Water Resources: Vulnerability from Climate Change and Population Growth. Science. 284-289 